\title{
Direct evidence that insulin does not down-regulate its own receptors in circulating monocytes of human newborns
}

\author{
M. Rodriguez, L.Alonso, E. Alvarez and E. Blázquez \\ Departamento de Bioquímica, Facultad de Medicina, Salamanca, Spain
}

\begin{abstract}
Summary. To determine the effect of insulin on its own receptor concentrations in circulating monocytes of normal human adults and full-term newborns, these cells were chronically exposed (2 $18 \mathrm{~h})$ to $10^{-9}$ to $10^{-7} \mathrm{~mol} / 1$ insulin at $37^{\circ} \mathrm{C}$ in vitro. The reduced ${ }^{125} \mathrm{I}$-insulin binding observed in monocytes from adult individuals was dependent on the concentration of unlabelled insulin and on the duration of exposure, while in the monocytes obtained from umbilical cord blood, insulin did not induce any reduction of insulin binding. The
\end{abstract}

modifications observed in insulin binding were accounted for by changes in receptor concentrations rather than by any change in receptor affinity for the hormone. These findings show that insulin does not down-regulate its own receptors in monocytes of human newborns.

Key words: Insulin receptors, down-regulation, monocytes, human newborns.
Chronic exposure to insulin has been shown to induce receptor down-regulation in a variety of cell types from humans and experimental animals; this mechanism has been suggested to play a major role in the pathogenesis of insulin resistance in many disease states [1] Although these findings indicate that insulin regulates its own receptor concentrations in adult individuals, there are several reports suggesting that this autorregulatory mechanism is absent during the fetal development of experimental animals. Thus, in vivo both receptor numbers and plasma insulin concentrations [2, 3] of fetal subjects increase with gestational age; in vitro, insulin lacks a direct effect on its receptors in rat fetal hepatocytes [4]. Moreover, in vivo full-term human fetuses have elevated concentrations of plasma insulin and insulin binding sites in monocytes from cord blood. This is even more noteworthy in the neonates of untreated diabetic mothers [5]. These findings suggestthough do not conclusively prove-that insulin does not have a direct down-regulatory effect on human fetal cells. To substantiate this point we have developed an experimental design with monocytes cultured from cord blood from full-term human newborns with a view to reproducing this phenomenon in vitro.

\section{Subjects and methods}

\section{Subjects}

The study subjects consisted of normal term infants delivered vaginally. In all cases, mothers were in good health and their pregnancies had no complications. All placentas were inspected and were macroscopically normal. All infants had normal birth weights and lengths and had no complications during the perinatal period. Control subjects consisted of healthy adult persons, 20-30 years of age.

\section{Preparation of cells}

Placental cord blood ( $80-100 \mathrm{ml}$ from each newborn) was collected in heparinised tubes at the time of delivery and $100 \mathrm{ml}$ heparinised blood were obtained from each adult volunteer. A preparation of mononuclear cells, consisting of lymphocytes and monocytes, was isolated by transfer over a Ficoll-Hypaque gradient by the method of Boyum [6]. Monocyte concentrations in cell suspensions were determined by $\alpha$-naphtlyl esterase staining [7]. Cell suspensions were counted in a hemocytometer.

\section{Preincubation of mononuclear cells with insulin}

Mononuclear cells were preincubated with RPMI 1640 medium (Flow Laboratories Ltd, Irvine, UK) with $20 \mathrm{mmol} / \mathrm{l}$ Hepes buffer and $2 \mathrm{mmol} / \mathrm{l}$ glutamine, $10 \%$ fetal calf serum, penicillin (100 IU/ $\mathrm{ml}$ ) and streptomycin $(100 \mu \mathrm{g} / \mathrm{ml})$, and were maintained at $37^{\circ} \mathrm{C}$ for $0-18 \mathrm{~h}$, in the presence $\left(10^{-9}\right.$ to $\left.10^{-7} \mathrm{~mol} / \mathrm{l}\right)$ or absence of insulin. All operations were performed asceptically. After preincubation, cells were carefully removed from the Petri dishes and transferred with the preincubation buffer to $50 \mathrm{ml}$-plastic centrifuge tubes, and spun at $600 \mathrm{~g}$ for $10 \mathrm{~min}$. The cells were immediately resuspended in $40 \mathrm{ml}$ of $100 \mathrm{mmol} / 1$ Hepes containing $120 \mathrm{mmol} / \mathrm{l} \mathrm{NaCl}$, $1.2 \mathrm{mmol} / 1$ magnesium sulphate, $1 \mathrm{mmol} / 1 \mathrm{EDTA}, 10 \mathrm{mmol} / 1 \mathrm{dex}-$ trose, $2.5 \mathrm{mmol} / 1$ sodium acetate and $10 \mathrm{mg} / \mathrm{ml}$ bovine serum albumin, pH 8 . The cells were sedimented again $(600 \mathrm{~g}, 5 \mathrm{~min})$ and resuspended in a fresh $40 \mathrm{ml}$ aliquot of the same buffer; after 25 min at $23{ }^{\circ} \mathrm{C}$ sedimentations and suspensions were repeated. After an additional $25 \mathrm{~min}$ at $23^{\circ} \mathrm{C}$, the cells were centrifuged again for $5 \mathrm{~min}$ and resuspended in the buffer used for the ${ }^{125} \mathrm{I}$-insulin binding studies. Trypan blue exclusion was determined by the ability of mononuclear cells to exclude $0.2 \%(\mathrm{w} / \mathrm{v})$ of the stain in the absence of albumin for $2 \mathrm{~min}$. 


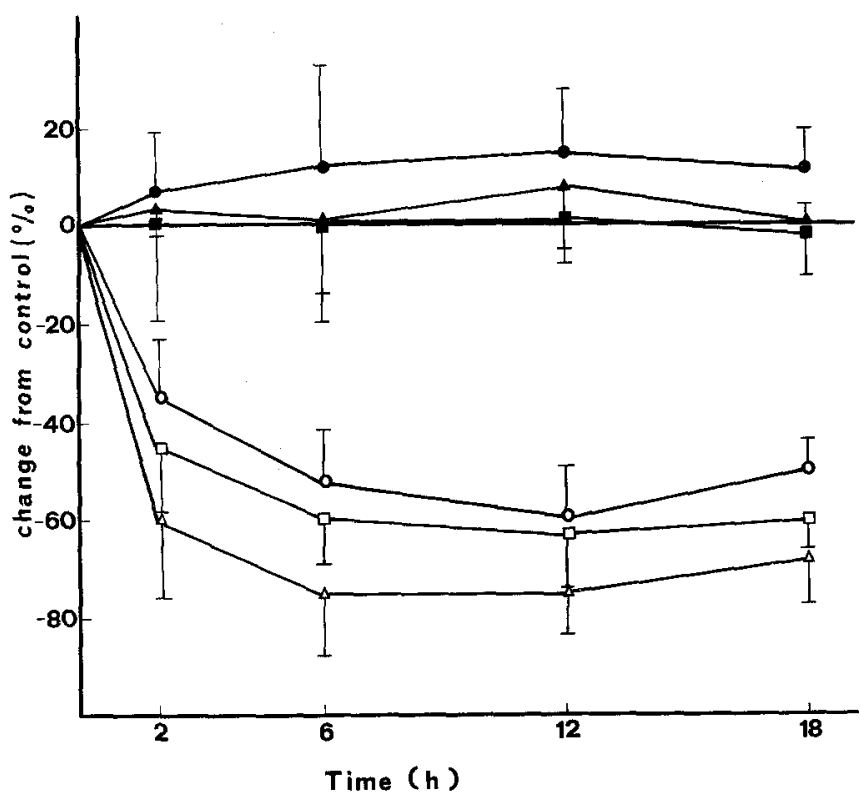

Fig. 1. Effect of preincubation with insulin on insulin binding to circulating monocytes of newborn and human adults. Results are expressed as percentage of change from cells preincubated in the absence of insulin (control). Mean \pm SEM, $n=3-5$.

and $\Delta$ : newborn circulating monocytes preincubated with $10^{-9}, 10^{-8}$ and $10^{-7} \mathrm{~mol} / 1$ insulin, respectively. $\mathrm{O} \longrightarrow, \square, \square$ and $\triangle \longrightarrow \triangle$ : adult circulating monocytes preincubated with $10^{-9}$, $10^{-8}$ and $10^{-7} \mathrm{~mol} / \mathrm{l}$ insulin, respectively

\section{${ }^{125}$ I-insulin binding to washed cells}

For binding studies, aliquots of the washed cells were incubated with ${ }^{125} \mathrm{I}$-insulin $(0.3 \mathrm{ng}$; specific activities of $240-300 \mu \mathrm{Ci} / \mu \mathrm{g}$ ) in a total volume of $0.5 \mathrm{ml}$ of assay buffer $(100 \mathrm{mmol} / 1$ Hepes, $120 \mathrm{mmol} / \mathrm{l}$ $\mathrm{NaCl}, 1.2 \mathrm{mmol} / 1$ magnesium sulphate, $1 \mathrm{mmol} / 1$ EDTA, $10 \mathrm{mmol} / 1$ dextrose, $2.5 \mathrm{mmol} / 1$ sodium acetate and $10 \mathrm{mg} / \mathrm{ml}$ of bovine serum albumin, $\mathrm{pH} 8$ ), at $23^{\circ} \mathrm{C}$ in the absence or presence of unlabelled insulin. After $3 \mathrm{~h}$, the cells were sedimented and separated from the assay buffer by ultracentrifugation. The radioactivity that was bound to cells in the presence of $16.6 \mu \mathrm{mol} / 1$ insulin was considered as nonspecific binding and was subtracted from the total binding values. Non-specific insulin binding was always lower than $5 \%$ of the total.

\section{Results}

The Ficoll-Hypaque mononuclear cell preparations from the blood of adults and umbilical cords contained a similar percentage of monocytes (25-33\%) with an erythrocyte contamination of less than $10 \%$. In addition, the final cell preparation obtained from cord blood had less than $1 \%$ of nucleated erythrocytes. In both preparations cell viability was confirmed by Trypan blue exclusion and was always greater than $97 \%$. Preincubation of cells with or without insulin did not modify cell viability. Insulin binding to mononuclear cells from adults decreased significantly as a function of the insulin concentration used during the preincubation period (Fig. 1). Thus, insulin binding (pg/10 $70^{7}$ monocytes; $n=3-6$ ) in cells preincubated for $18 \mathrm{~h}$ in the absence of the hormone (12 \pm 2$)$ was significantly

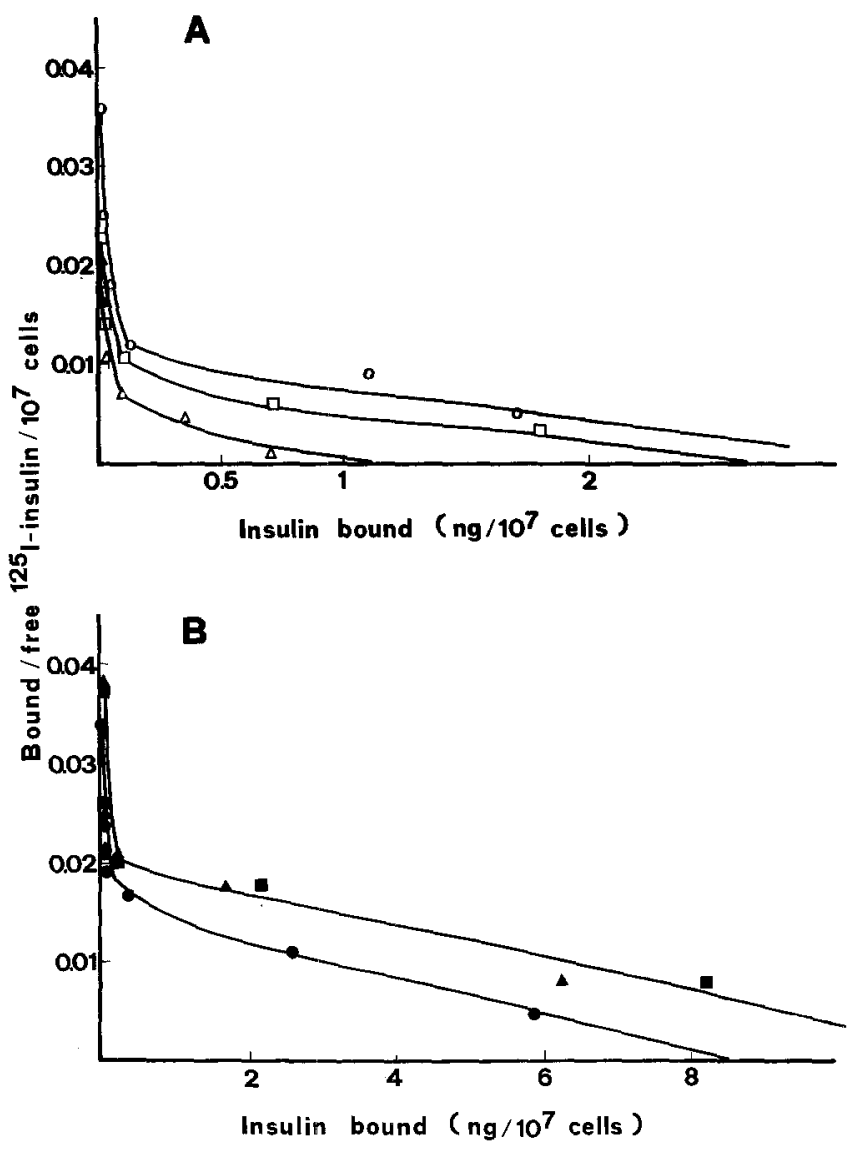

Fig. 2. Scatchard analysis of insulin binding to circulating monocytes of adults (panel A) and human newborns (panel B) previously preincubated at $37^{\circ} \mathrm{C}$ for $18 \mathrm{~h}$ in the absence $(\mathrm{O}-\mathrm{O},-\infty)$ or presence of $10^{-8}(\square-\square, \square-\square)$ and $10^{-7}(\triangle-\triangle$, $\Delta-\Delta) \mathrm{mol} / 1$ insulin, $n=3-6$

greater $(p<0.01)$ than in those preincubated with $10^{-8} \mathrm{~mol} / 1(7 \pm 2)$ and $10^{-7} \mathrm{~mol} / 1(3 \pm 1)$ of unlabelled insulin. However, in newborn mononuclear cells, both the time of preincubation with insulin and the insulin concentrations used did not modify insulin binding (Fig. 1). In fact, insulin binding (pg/ $10^{7}$ monocytes; $n=3-6)$, was not significantly different $(p>0.05)$ between the cells preincubated for $18 \mathrm{~h}$ in the absence of the hormone (20 \pm 5$)$ as compared with those preincubated with $10^{-8}$ and $10^{-7} \mathrm{~mol} / 1$ of unlabelled insulin $(22 \pm 3$ and $22 \pm 3$ respectively). Compared with adult cells, insulin binding to newborn mononuclear cells was always greater when the cells were preincubated both in the absence or presence of different insulin concentrations $(p<0.01)$.

With a view to determining whether the changes in ${ }^{125} \mathrm{I}$-insulin binding might be related to modifications in insulin receptor concentrations, the bound/free ratio of the labelled hormone was plotted as a function of the bound hormone to all groups of mononuclear cells according to Scatchard (Fig.2). The results obtained with this procedure could not be fitted to a single straight line but gave a curvilinear graph compatible with negative co-operativity, or to at least two 
orders of binding sites: high affinity/low capacity and low affinity/high capacity. Analysis of the data indicated that the decrease in binding of ${ }^{125} \mathrm{I}$-insulin in adult mononuclear cells previously preincubated in the presence of insulin was due to a loss of receptor numbers per cell (Fig. 2). However, newborn cells preincubated in the presence of insulin showed the same or even greater number of insulin binding sites (Fig. 2). Changes in the number of insulin binding sites between both groups of cells were not related to a different pattern of insulin association or hormone degradation.

\section{Discussion}

Our results show that insulin does not decrease its own receptor concentrations in circulating monocytes from full-term human newborns. These findings were obtained with an experimental design in which cell viability and insulin binding to the monocytes were not altered by the effect of preincubation. Nucleated erythrocytes were found in preparations from cord blood; these cells have insulin receptors with properties comparable to those observed in other target tissues. However, the number of these cells in the mononuclear cell preparations was so small that they did not interfere with the data concerning insulin binding to monocytes, as has been reported by other authors.

The decrease in receptors by the cells from adult individuals cannot be ascribed to simple contamination of receptors by the insulin added during preincubation. The hormone dissociation procedure followed, and the subsequent washing of the cells proved to be sufficient to remove unlabelled insulin, as has been described by other authors [1]. Nevertheless, if dissociation had not occurred, a progressive decrease in insulin binding would not have been observed over time and the shapes of the competition curves could have been altered, though this did not occur. In addition, the monocytes obtained from umbilical cord blood did not decrease their number of insulin binding sites after preincubation at several insulin concentrations.

In our experimental model, the reduced binding of ${ }^{125}$-I-insulin to monocytes of adult individuals was dependent on the insulin concentration during the preincubation period and on the duration of exposure, while in monocytes from full-term newborns preincubated with insulin, this hormone did not induce a decrease in insulin binding. The modification observed in insulin binding was fully accounted for by the changes in receptor concentrations rather than by any change in receptor affinity for the hormone.

In the present study we reproduced in vitro the insulin-dependent regulation of insulin receptor concentrations in monocytes from adult individuals and we present direct evidence that insulin does not down-regulate its own receptors in newborn monocytes; this lends further support to the indirect observations ob- tained in vivo in the newborns of untreated diabetic mothers in which plasma insulin concentrations and the number of insulin receptors in monocytes are greater than those of normal infants [5]. Conversely, a strict metabolic control of diabetic mothers restores insulin secretion and insulin binding to circulating monocytes in the fetus to near-normal concentrations [8].

In the fetus the strong increase in the insulin/glucagon ratio [2], earlier development of insulin receptors [3] and tissue sensitivity to this hormone [9], together with the continuous supply of nutrients by placental transfer, facilitate the anabolic processes needed for fuel storage and organ development [10]. In addition, the absence of an insulin receptor down-regulation in fetal cells could further favour the anabolic processes during intrauterine life.

Acknowledgements. The authors wish to thank the generous collaboration of the Obstetrics Department of Hospital Clinico Universitario, Salamanca. This work was supported by grants for the Comision Asesora de Investigación Científica y Técnica and the Junta de Castilla y León.

\section{References}

1. Gavin JR, Roth J, Neville DM, De Meyts P, Buell DN (1974) Insulin dependent regulation of insulin receptors concentrations: a direct demonstration in cell culture. Proc Natl Acad Sci USA 71: 84-88

2. Blázquez E, Sugase T, Blázquez M, Foà PP (1974) Neonatal changes in the concentrations of rat liver cyclic AMP of serum glucose, free fatty acids, insulin pancreatic and total glucagon in man and in the rat. J Lab Clin Med 83: 957-967

3. Blázquez E, Rubalcava B, Montesano R, Orci L, Unger RH (1976) Development of insulin and glucagon binding and the adenylate cyclase response in liver membranes of the prenatal, postnatal and adult rats: evidence of glucagon "resistance". Endocrinology 98: 1014-1023

4. Menuelle P, Plas C (1981) Relationship between insulin binding to glycogenesis in cultured fetal hepatocytes. Diabetologia 20: $647-653$

5. Neufeldt ND, Kaplan SA, Lippe BM, Scott M (1978) Increased hepatocyte receptor binding of ${ }^{125} \mathrm{I}$-insulin in infants of gestational diabetic mothers. J Clin Endocrinol Metab 47: 590-595

6. Boyum A (1968) Separation of leukocytes from blood and bone marrow. Scand J Clin Lab Invest 21: 77-89

7. Yam LT, Li CY, Crosby WH (1971) Cytochemical identification of monocytes and granulocytes. Am J Clin Pathol 55: 282-290

8. Neufeldt ND, Kaplan SA, Lippe BM (1981) Monocyte insulin receptors in infants of strictly controlled diabetic mothers. J Clin Endocrinol Metab 52: 473-476

9. Clark CM (1971) Carbohydrate metabolism in the isolated fetal rat heart. Am J Physiol 220: 583-588

10. Susa JB, McCormick KL, Widness JA, Singer DB, Oh W, Admsons K, Schwartz R (1979) Chronic hyperinsulinemia in the fetal rhesus monkey. Effects on fetal growth and composition. Diabetes $28: 1058-1063$

Received: 30 July 1987

Professor Enrique Blázquez

Departamento de Bioquímica

Facultad de Medicina

Universidad Complutense

E-28040 Madrid

Spain 